\title{
О РАБОТЕ КРУГЛОГО СТОЛА, ПОСВЯЩЕННОГО ЮБИЛЕЮ МАРИНЫ ГЛЕБОВНЫ МОШКОВОЙ
}

\author{
(C) 2020 г. М. К. Хабдулина, Я. А. Лукпанова
}

\begin{abstract}
Статья содержит анализ работы Круглого стола, посвященного юбилею доктора исторических наук, профессора М. Г. Мошковой, который проходил в Москве, в Институте археологии РАН 12-13 ноября 2019 г. В статье кратко изложены основные вехи биографии Марины Глебовны Мошковой, вклад в археологию Евразии, в разработку и исследование фундаментальных проблем савромато-сарматской археологии и роли этого культурного феномена в истории древних сообществ евразийского пространства. Указано значение сводных трудов по археологии раннего железного века степной Евразии, осуществленных при участии и редакторской деятельности М. Г. Мошковой. Огромный вклад юбиляр внесла в подготовку и постоянную поддержку археологических кадров региональных школ сарматоведения. Во второй части статьи дан анализ основных проблем, озвученных в докладах участников Круглого стола. Они касаются традиционных вопросов изучения раннесарматской археологии: хронологии, периодизации, этнической принадлежности.
\end{abstract}

Ключевые слова: археология, М. Г. Мошкова, Евразия, Южный Урал, савроматы, сарматы, периодизация, хронология, происхождение, элитные комплексы

\section{Введение}

В 2019 г. у известного археолога, одного из основателей школы сарматоведения доктора исторических наук, профессора Марины Глебовны Мошковой был юбилей. Поздравляя ее с этим славным событием, Отдел скифо-сарматской археологии Института археологии РАН провел 12-13 ноября 2019 г. Круглый стол «Археология ранних кочевников евразийской степи: актуальные проблемы и перспективы их решения». В работе Круглого стола приняли участие археологи из вузов и академических учреждений Казахстана, России, Германии. География участников включала территорию степного пространства от Крыма до Центрального Казахстана, столь обширный охват территории включал в себя практически весь аре- ал исследовательских интересов и полевых работ Марины Глебовны.

М. Г. Мошкова (Дубинская) родилась 30 июля 1929 г. в г. Киеве. В 1952 г. окончила исторический факультет МГУ им. М. В. Ломоносова [60 лет кафедре..., 1999, с. 258]. После окончания аспирантуры Института истории материальной культуры АН СССР (ныне Институт археологии РАН - прим. авт.), в 1956 г защитила кандидатскую диссертацию «Производство и основной импорт у сарматов Нижнего Поволжья», научный руководитель Б. Н. Граков [Мошкова, 1956]. С 1956 г. и по настоящее время работает в Институте археологии РАН в Отделе скифо-сарматской археологии, где прошла все этапы служебного научного роста от младшего 


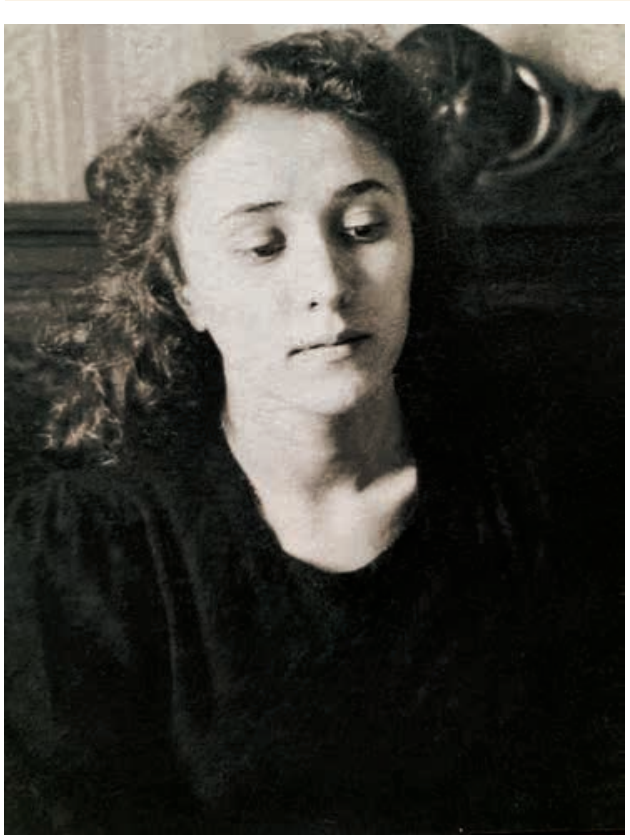

Рис. 1. Марина Глебовна Мошкова. Университетские годы.

Фото из архива М. Г. Мочковой предоставлено Л. А. Краевой

Fig. 1. Marina G. Moshkova. University years. Photo from the archive

of M.G. Moshkova courtesy of L.A. Kraeva

до главного научного сотрудника. В 1989 г. М. Г. Мошкова защитила докторскую диссертацию на тему «Пути и особенности развития “савроматосарматской” культурно-исторической общности» [Мошкова, 1989а]. В 1993-2002 гг. была заведующей Отделом скифо-сарматской археологии. С 1990 г. Марина Глебовна - член Ученого Совета, член диссертационного совета ИА РАН и член диссертационного совета кафедры археологии и этнологии исторического факультета МГУ им. М. В. Ломоносова. С 1997 г. - член редакционного совета журнала «Российская археология». Столь обширная и многогранная деятельность совмещалась с научной работой, руководством аспирантами, тесными связями с вузами Поволжья,
Подонья, Южного Урала и Западного Казахстана. Активные научные связи Марина Глебовна поддерживала с основателем западноказахстанской археологической школы Г. А. Кушаевым [Мошкова, Кушаев, 1973, с. 58]. Вместе с ним воспитала ведущих исследователей раннего железного века Западного Казахстана - Б. Ф. Железчикова, В. А. Кригера, С. Ю. Гуцалова.

Со студенческих лет Марина Глебовна принимает участие в археологических экспедициях на территории Украины, Дагестана, Нижнего Поволжья, которые сформировали интерес к савромато-сарматской тематике. Самостоятельные раскопки вначале в качестве начальника отряда, а потом и Оренбургской (впоследствии Южно-Уральской) археологической экспедиции проводились ею в 1958-1980 гг. Наиболее значительный вклад Марина Глебовна внесла в исследование археологии Оренбуржья. Возле города Орска в течение ряда лет проводила раскопки могильника Новый Кумак, который дал материалы всех периодов тысячелетней истории сарматов.

За эти заслуги, как было оглашено в начале Круглого стола Ученым секретарем ИА РАН М. В. Вдовиченко, двум улицам г. Орска присвоены имена археологов: К. Ф. Смирнова и М. Г. Мошковой. Это примечательная новость, что труд археологов оценен столь высоко, была встречена аплодисментами участников Круглого стола. Государственное Постановление о присвоении улицам имен главных исследователей древней истории Оренбуржья вывешено на сайте ИА PAH.

Вклад М. Г. Мошковой в археологию Евразии. М. Г Мошкова автор 
более 130 научных трудов, среди которых кроме монографий и научных статей большое значение имеют сводные работы по скифо-сарматской археологии в серии «Археология СССР». Огромный труд под ее руководством выполнен в выпусках Статистической обработки погребальных памятников Азиатской Сарматии по савроматской эпохе, раннесаматской, среднесарматской и позднесарматской культурам. Эти выпуски вышли в 1994, 1997, 2002, 2009 гг. [Статистическая, 1994; 1997; 2002; 2009]. Это подведение результатов столетних исследований археологов и экспедиций на пространстве существования «савромато-сарматской» культурноисторической общности. По единому принципу в единый блок источников сведены материалы по 5000 погребальных комплексов двух географических регионов: Волга-Дон и Южное Приуралье [Статистическая, 1997, c. 10]. Каждый выпуск имел свой коллектив авторов, но общее руководство в течение почти 20 лет осуществляла М. Г. Мошкова. Это огромная работа по сбору, работе в архивах, оформлению и сохранению общей структуры всех выпусков, строгость изложения теоретических выводов выделяют постоянный исследовательский стиль научного подхода М. Г. Мошковой. Тщательный анализ с применением количественных методов заложил фундаментальную источниковую базу для дальнейших сравнений и анализов. За такой титанический труд мог взяться ученый с чувством личной ответственности перед любимой наукой и поколениями исследователей.

Главное направление ее научных интересов - история и археология раннесарматских племен, сформировалось уже к середине 50-х годов
XX в., что видно по теме кандидатской диссертации (1956). В 50-60-е годы ХX в. в связи со строительством промышленных объектов в Восточной Европе и Южном Приуралье развернулись масштабные археологические работы. В исследование включились не только академические экспедиции, но и местные коллективы вузов, музеев. В итоге многократно возросла база источников. Первое обобщение раннесарматских комплексов, достигших 542 погребений, было сделано в 1963 г. [Мошкова, 1963, с. 5].

Через 10 лет вышла монография, посвященная основным проблемам изучения раннесарматской (прохоровской) культуры [Мошкова, 1974]. Эта монография занимает первые позиции в цитировании исследователей по раннему железному веку Урало-Поволжья. В ней расставлены акценты в происхождении раннесарматской археологической культуры, намечен механизм и место трансформации савроматских традиций в раннесарматские в результате миграций и культурных влияний. Выход монографии связан с дискуссиями по проблемам культурно-географического единства савроматской культуры VIIV вв. до н.э. и локальной асинхронности ведущих признаков культуры в рамках двух географических регионов: доно-волжского и южноуральского. М. Г. Мошкова, анализируя всю сложившуюся к этому времени базу источников по раннему железному веку Южного Урала и окружающего пространства, выделила в качестве основных признаков классификации и обобщения формы погребальных конструкций и керамику. По этим признакам сделан вывод о формировании раннесарматской культуры в Южном Приуралье в IV в. до н.э. при участии 


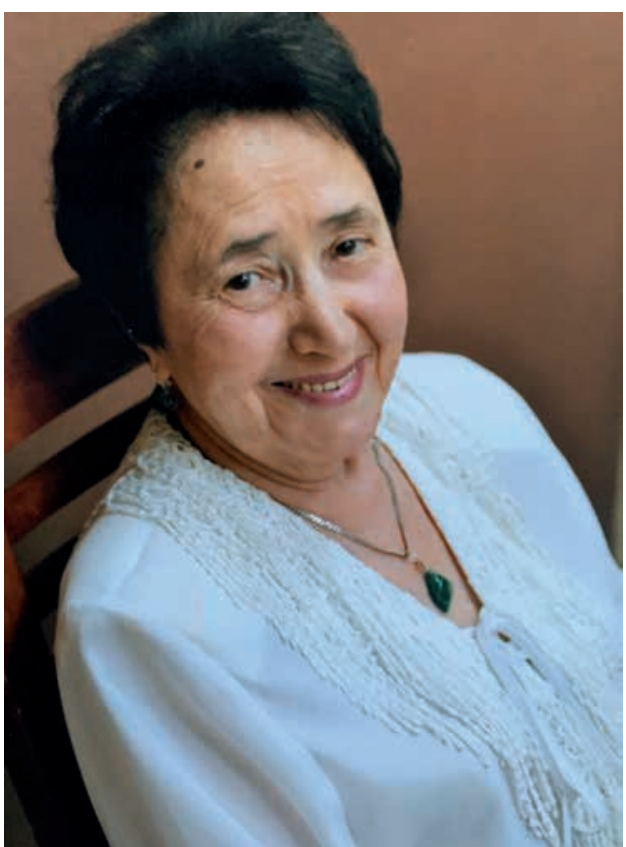

Рис. 2. Марина Глебовна Мошкова. Фото из архива М. Г. Мошковой предоставлено Л. А. Краевой

Fig. 2. Marina G. Moshkova. Photo from the archive of M.G. Moshkova courtesy of L.A. Kraeva

гороховской и иткульской культур лесостепного Зауралья и культурным связям с Восточным Приаральем и Центральным Казахстаном [Мошкова, 1974, с. $47,48,51]$.

В многотомном издании по Археологии СССР, предпринятом ИА АН СССР в конце 80-х годов $\mathrm{XX}$ в., Марина Глебовна является одним из основных авторов по скифосарматской археологии. В томе «Степи европейской части СССР в скифосарматское время» (1989) во второй части ею написана пятая глава и совместно с А. И. Мелюковой введение. Это логично, так как том посвящен истории и археологии «двух наиболее значительных этнических общностей степей Восточной Европы - скифской и савромато-сарматской» [Мелюкова, Мошкова, 1989, с. 7].
Раздел по савромато-сарматам начинается с краткого очерка истории савромато-сарматских племен. В нем изложены вопросы этногеографии, этнических наименований и историографии изучения этих вопросов в советской археологии. За основу взяты письменные сведения античной и эллинистической историкогеографической литературы. Во вступительной части изложена историография основных проблем изучения савромато-сарматской общности: периодизация, хронология, происхождение, расселение, этническая и этнокультурная принадлежность. Подведен итог всех мнений по этим вопросам на период середины 80-х годов XX в. [Мошкова, 1989б, с. 158164]. Это прекрасный справочный источник и достоверная основа для дальнейших историографических исследований.

В изложении раннесарматской, среднесарматской и позднесарматской археологических культур, следуя структуре тома, описаны виды памятников, погребальный обряд, ведущие категории инвентаря. Отдельную ценность представляют карты памятников с полным подстрочным списком [Мошкова, 1989б, c. 170, 176]. Отдельно вынесен очерк по основным видам хозяйства, общественным отношениям, связи сарматов с окружающим миром [Мошкова, 1989в, с. 202-214].

Таким образом, в томе «Степи европейской части СССР в скифосарматское время» представлен очерк развития более чем тысячелетней истории сарматской археологической культуры, и содержание очерка подтверждает вывод, что сарматская культура - феноменальное явление, распространившееся на огромной 
территории и сыгравшее значительную роль в этно- и культурогенезе древних племен Евразии [Мошкова, 1989B, c. 214].

В 1992 г. вышло продолжение издания археологии раннего железного века азиатской части евразийского пространства. Это было тяжелое для страны время: распад Советского Союза и вытекающие из этого экономические трудности. Поэтому тираж издания был сокращен. Ответственным редактором этого тома является М. Г. Мошкова. Ею написаны введение, заключение и в соавторстве два теоретических раздела, посвященные анализу основных проблем в изучении памятников раннего железного века двух огромных географических регионов: Среднеазиатско-Казахстанского и Сибирского [Мошкова, 1992, с. 5-8; $21-30 ; 151-160 ; 312-318]$.

Во введении указано, что, следуя географическому принципу, том состоит из двух частей: Средняя Азия - Казахстан и Сибирский регион, включая Алтай, Туву, Забайкалье. Таким образом, стояла задача охватить огромную, разнородную по природноклиматическим условиям территорию от лесостепной полосы Западной Сибири до горных районов Тянь-Шаня, Памира, Саяно-Алтая - территорию, населенную в раннем железном веке разными по хозяйственной специфике, уровню политического устройства, этнической, языковой принадлежности племенами, и изложить археологический материал протяженностью в 1200 лет. Если учесть, что разным был авторский коллектив, различны степень исследованности регионов, исследовательские подходы в изучении и интерпретации археологических источников, то можно представить труд ответственного редактора, задачей которого было сохранить общую структуру, изложение материала, оформление иллюстраций, сроки работы. Этот титанический труд по подготовке и изданию второго тома по раннему железному веку Евразии был осуществлен М. Г. Мошковой.

Если том по скифо-сарматской археологии европейской части ко времени издания был подготовлен большим количеством обобщающих монографий по скифской, савроматской и сарматским культурам, то археология раннего железного века азиатской части СССР не располагала достаточным количеством археологических источников. Их не было в рамках двух выделенных географических пространств (Средняя Азия - Казахстан и Сибирский регион) и отдельных периодов или крупных хронологических срезов. Археология азиатской части носила характер отдельных, мало связанных друг с другом локальных ареалов в пространственном, хронологическом, культурном отношении. Лучше был изучен сибирский регион (тагарская, таштыкская, хуннская культуры). В среднеазиатском регионе сохранялась практика отдельного изучения оседлых памятников (поселений, городов) и погребальных объектов. В этот том были включены лесостепные культуры раннего железного века Зауралья и Западной Сибири. Как пишет Марина Глебовна, это связано с двумя факторами: общностью экономического строя - существованием у оседлого лесостепного населения яйлажнопастушеской, полукочевой форм скотоводства и тесными контактами с западными и южными кочевыми coceдями, которые были постоянными на всем протяжении раннего железного века [Мошкова, 1992, с. 8]. 
В теоретических разделах изложены проблемы происхождения кочевого скотоводства, характеристика пастбищно-кочевой системы хозяйствования, краткая история изучения двух географических регионов. Среди проблем раннего железного века Средней Азии и Казахстана внимание обращено на происхождение, начало формирования сакской археологической культуры. Приведены две концепции: автохтонная от эпохи поздней бронзы и миграционная вследствие перемещения племен бегазы-дандыбаевской культуры на юг, в Семиречье [Вайнберг и др., 1992, с. 25-26]. Большое место занимает анализ изучения идеологии и искусства саков, этногеография сакских племен, названия которых известны по персидским и античным источникам. Подведены итоги изучению усуньской проблемы. Эти главы отражают результат изученности сако-усуньской археологии на конец 80-х годов XX в. В настоящее время появились новые материалы и трактовки. Разработка их будет основана на предшествующих обобщениях, сделанных в сводном труде «Степи азиатской части СCCP в скифосарматское время».

В целом, том по раннему железному веку азиатской части Евразии имеет большое значение в дальнейшем изучении общих и частных проблем отдельных регионов, эпох, археологических культур и общностей.

Работа Круглого стола. От Казахстана приняли участие М. К. Хабдулина и Я. А. Лукпанова. Всего был заслушан 21 доклад. В какой-то мере Круглый стол является продолжением периодически созываемых международных конференций по сарматской археологии. Организаторами Первой конференции, специально посвященной сарматской археологии и истории, были М. Г. Мошкова и Б. Ф. Железчиков. Конференция с большим успехом прошла в Азове в 1988 г. Тогда же возникла идея сделать конференцию периодичной с интервалом в три года и избрать постоянно действующий научный Оргкомитет во главе с М. Г. Мошковой. Под ее руководством прошли четыре конференции: в Волгограде (II) в 1994 г., в Азове (III) в 1997 г., в Самаре (IV) в 2000 г. Пятая международная конференция состоялась в Анапе в 2004 г. На этой конференции председателем постоянного Оргкомитета был избран Л. Т. Яблонский [Яблонский, 2007, с. 5]. Следующие конференции прошли в Челябинске (2007 г.), в Азове (2011 г.).

Таким образом, конференции по сарматской тематике, инициированные организаторским талантом М. Г. Мошковой - еще одна грань научного вклада Марины Глебовны в развитие сарматологии. И об этом упоминали все выступающие на Круглом столе. К сожалению, сама Марина Глебовна не присутствовала из-за плохого самочувствия, но весь ход работы Круглого стола снимался на видео и был передан организаторами юбиляру.

Открыли работу Круглого стола заведующий отделом скифосарматской археологии А. А. Малышев и ученый секретарь ИА РАН М. В. Вдовиченко. С приветственными словами и благодарностью выступили археологи, которые под научным руководством М. Г. Мошковой защитили кандидатские диссертации, выбрали свой путь в профессию, участвовали в экспедициях под ее руководством - М. К. Хабду- 
лина, Л. Н. Корякова, А. Д. Таиров, А. П. Медведев.

М. К. Хабдулина в кратком сообщении «М. Г. Мошкова мой научный руководитель» рассказала о том, что поступила в аспирантуру Института археологии АН СССР к К. Ф. Смирнову и под его руководством прошли два года ее аспирантской жизни. После кончины К. Ф. Смирнова (1980 г.) отдел скифо-сарматской археологии назначил научным руководителем М. Г. Мошкову. Как вспоминает М. К. Хабдулина, аспирантура была самым значительным событием и главной научной школой. Марина Глебовна заложила ответственное отношение к логике и стилю научного текста. Поля глав диссертации после ее проверки пестрели постоянными замечаниями: «не понятно», «стиль!», «нет логики в изложении» и прочее. И постепенно это сформировало постоянную самопроверку, строгость изложения. Как было сказано М. К. Хабдулиной: она надеется, что уроки академического письма, приобретенные под руководством М. Г. Мошковой, сохранила и развила, теперь вкладывает это в своих учеников - студентов, магистрантов, докторантов. Людмила Николаевна Корякова также тепло вспоминала свои аспирантские годы, в результате которых отношения с научным руководителем переросли в профессиональную дружбу двух ученых. Обмен мнениями был крайне полезен для обеих, так как саргатская археологическая культура лесостепного Зауралья - тема диссертации Л. Н. Коряковой являлась одной из главных культур, принявших участие в формировании раннесарматской (прохоровской) культуры.

Самое общее впечатление от конференции заключается в крайней заинтересованности всех участников в содержании докладов. Зал был небольшой, вмещал 30-50 человек, в основном присутствовали сами докладчики. Для каждого доклада было выделено 30 минут, они сопровождались презентациями и очень подробно обсуждались, участники конференции дискутировали, отвечали на многочисленные вопросы.

Доклады конференции можно поделить по региональному признаку. Больше всего докладов было по археологии Южного Приуралья - шесть, сюда же можно причислить два доклада по Южному Зауралью (А. Д. Таиров и Л. Н. Коряковой) и один доклад (М. К. Хабдулиной) по тасмолинской археологической культуре Центрального Казахстана. В докладах по Южному Приуралью были представлены яркие комплексы элитных погребений раннесарматского времени (Таксай, Кырык-Оба, Лебедевка - докладчик Я. А. Лукпанова; Высокая могила - Студеникин Мар - докладчики С. В. Сиротин, Д. С. Богачук, К. С. Окороков; I Прохоровский могильник - докладчик Д. В. Мещеряков).

Актуальной проблемой в разработке механизма трансформации археологических культур сарматского мира становится исследование социальной истории. Этой теме были посвящены отдельные конференции. Материалы для этого представлены элитными курганами, открытыми в Приуралье, Поволжье и на Дону. На Круглом столе этот вопрос был отражен в докладе A. X. Гильмитдиновой «Типы погребальных конструкций как маркеры социальной дифференциации ранних кочевников Южного Урала второй половины VI-IV в. до н.э.». 
В докладе Л. Н. Коряковой «Саргатская культура в системе культурных миров Евразии» была представлена широкая панорама связей и контактов лесостепной археологической культуры V в. до н.э. - V в. н.э. с соседними и далекими цивилизациями Старого Света. Кратко изложены итоги раскопок последних десятилетий, показан ареал охвата памятников раннего железного века археологическими раскопками. Эта лесостепная культура, занимающая территорию от Зауралья до Барабинской низменности, представлена городищами, поселениями, могильниками и элитными курганами. Все это, по мнению Л. Н. Коряковой, укладывается в трактовку государственного устройства социально-политической истории саргатской общности.

В докладе А. Д. Таирова «Погребения мужчин-воинов могильника Кичигино І» дана характеристика погребального обряда элитного кургана степной полосы Южного Зауралья $\mathrm{VI}-\mathrm{V}$ вв. до н.э. Дано описание коллективной гробницы с захоронениями воинов с большим количеством золотых украшений, колчанных наборов и ритуальных сосудов. Набор наконечников стрел и предметы искусства характеризуют древнепрохоровскую стадию раннего железного века Южного Зауралья.

Доклад М. К. Хабдулиной «Новые открытия в тасмолинской археологической культуре степной Сарыарки» содержит результаты археологических работ последних десятилетий. Указано, что в монографии М. Г. Мошковой 1974 г. были привлечены материалы тасмолинской культуры для аргументации влияния Тасмолы на формирование раннесарматской (прохоровской) культуры. С тех пор произошли разительные перемены в исследовании раннего железного века Центрального Казахстана. Открыты и изучаются новые виды памятников: поселения, «царские» курганы, каменные скульптуры. Сделаны массовые радиоуглеродные анализы и получены новые даты. Тасмолинская археологическая культура оказалась культурой раннесакского времени VIII - начала V в. до н.э. По-прежнему загадочно отношение курганов «с усами» к тасмолинской археологической культуре, т.к. часть открытых каменных изваяний обнаружены у каменных дорожек курганов «с усами». Значительные серии предметов искусства получены из «царских» курганов Сарыарки. В целом, тасмолинская культура входит в ареал сакской культурной провинции азиатской части Евразии.

Два доклада были заслушаны по археологии Северного Кавказа. Этот регион дает социально-значимые комплексы для решения вопросов этнической принадлежности, хронологии освоения этих территорий в сарматское время. Дискуссионными остаются проблемы начальной даты проникновения сарматов на запад, в Северное Причерноморье. В докладе В. Е. Маслова, А. Р. Канторовича «Некоторые итоги изучения могильника Новозаведенное III в 2019 г. » (могильники раннескифской эпохи в Георгиевском районе Ставропольского края - прим. авт.) изложены результаты раскопок могильников в последнем полевом сезоне, исследование которых ведется уже много лет. Главной проблемой является вопрос длительного стационарного присутствия ранних скифов на Северном Кавказе. Доклад В. В. Кропотова «Актуальные проблемы изучения раннесарматских 
памятников Северного Причерноморья» касается затянувшейся дискуссии о дате и этнической принадлежности памятников ранних сарматов степного Причерноморья.

Восемь выступлений на конференции были посвящены анализу вещей. Многие из докладов являются продолжающимися темами. Например, классификация, построение типологических корреляционных схем были изложены в докладе Л. А. Краевой «История изучения и проблемы классификации сарматской керамики». Л. А. Краева в течение ряда лет изучает керамику сарматских памятников Западного Казахстана и Оренбуржья, и по этой теме ею накоплен значительный объем источников. Исследование керамики крупных курганов Башкирии было представлено в докладе Н. С. Савельева, С. В. Сиротина «Керамические комплексы некрополей Переволочан I и Переволочан II».

Тема жертвенных подношений прозвучала в докладе В. П. Глебова, А. В. Дедюлькина «Ритуальные клады: современное состояние проблемы». В докладе приведены примеры жертвенных подношений (состав, место расположения, датировка). В вопросе функционального назначения указана их коммуникативная роль между миром живых и миром мертвых.

К этой же категории находок относятся бронзовые котлы, широко распространенные в кочевнических комплексах Евразии. На заседании Круглого стола о типологии и предназначении бронзовых котлов, а также об одном из редких видов данных предметов было изложено в докладе С. В. Демиденко, К. С. Окорокова «Об одном из редких типов бронзовых литых котлов Евразии».
Об отдельных категориях вещей, технике их изготовления, происхождении докладывалось в выступлениях О. В. Аникеевой «Каменные печати могильника Филипповка I», B. М. Клепикова «Нестандартное клинковое оружие из погребений IV в. до н.э. в Нижнем Поволжье», Е. В. Лыловой «К вопросу о датировке спиралевидных височных подвесок из погребений ранних кочевников Южного Урала», М. Ю. Трейстер «Импортные статуэтки в погребениях кочевников Азиатской Сарматии».

Доклад С. И. Лукъяшко «Виды охоты у кочевников Евразии в раннем железном веке» был построен по аналогии с видами охоты на диких животных и использовании их приемов у кочевников. Необходимо указать, что это направление подробно анализируется в этнографических исследованиях при описании охоты как метода воинской тактики и обучения у кочевников средневековья. К. С. Окороков представил уже третий доклад на этой конференции по теме «Расшитые бисером рукава женского костюма из погребения 2 кургана 1 некрополя Филипповка I». Материалы элитного могильника Филипповка I, исследованного в 2004-2009 гг. под руководством Л. Т. Яблонского, дали разнообразный материал по предметам быта, торевтике, вооружению, погребальному обряду и будут представлять интерес еще не одному поколению исследователей. Могильник Филипповка I по комплексу вещей датируется второй половиной $\mathrm{V}-\mathrm{IV}$ в. до н.э.

Таким образом, доклады и дискуссии, развернувшиеся на Круглом столе, посвященном юбилею М. Г. Мошковой, продемонстрировали современное состояние проблем 
сарматской археологии: по вопросам хронологии и периодизации (в т.ч. по выделению локальных культурнохронологических горизонтов), механизмам трансформации, территории происхождения отдельных культурных образований. В перспективе изучения стоят проблемы рассмотрения этнических контактов, связей с античным и переднеазиатским миром, культурных достижений и др. Открытие элитных курганов ставит перед исследователями задачу изучения духовной культуры, мировоззрения савромато-сарматских кочевников. В настоящее время ярко проступает значение мультикультурного евразийского пространства срединной Евразии во всемирно-историческом процессе.

\section{ЛИТЕРАТУРА}

1. 60 лет кафедре археологии МГУ им. М.В. Ломоносова: тез. докл. юбилейной конф., посвящ. 60-летию кафедры археологии исторического факультета МГУ им. М.В. Ломоносова (г. Москва, 20-24 декабря 1999 г.). М.: МГУ им. М.В. Ломоносова, 1999. $276 \mathrm{c.}$

2. Боковенко Н.А., Мошкова М.Г., Могильников В.А. Основные проблемы в изучении памятников древних скотоводов Западной Сибири, Южной Сибири и Забайкалья // Степи азиатской части СССР в скифо-сарматское время. Археология СССР / отв. ред. М.Г. Мошкова. М.: Наука, 1992. С. 151-160.

3. Вайнберг Б.В., Горбунова Г.Г., Мошкова М.Г. Основные проблемы в изучении памятников древних скотоводов Средней Азии и Казахстана // Степи азиатской части СССР в скифо-сарматское время. Археология СССР / отв. ред. М.Г. Мошкова. М.: Наука, 1992. С. 21-30.

4. Мелюкова А.И., Мошкова М.Г. Введение // Степи европейской части СССР в скифо-сарматское время. М.: Наука, 1989. С. 5-8.

5. Мошкова М.Г. Производство и основной импорт у сарматов Нижнего Поволжья: автореф. дис. ... канд. ист. наук. М.: ИИМК, 1956. 14 с.

6. Мошкова М.Г. Памятники прохоровской культуры // САИ. Д1-10. М.: Наука, 1963. $56 \mathrm{c}$.

7. Мошкова М.Г. Происхождение раннесарматской (прохоровской) культуры. М.: Наука, 1974. 52 с.

8. Мошкова М.Г. Пути и особенности развития «савромато-сарматской» культурно-исторической общности: научный доклад ... дис. ... докт. ист. наук. М.: ИА АН ССCР, 1989a. 47 c.

9. Мошкова М.Г. История изучения савромато-сарматских племен // Степи европейской части СССР в скифо-сарматское время. Археология СССР / отв. ред. А.И. Мелюкова. М.: Наука, 1989б. С. 158-164.

10. Мошкова М.Г. Хозяйство, общественные отношения, связи сарматов с окружающим миром // Степи европейской части СССР в скифо-сарматское время. Археология СССР / отв. ред. А.И. Мелюкова. М.: Наука, 1989в. С. 202-214.

11. Статистическая обработка погребальных памятников Азиатской Сарматии. Вып. І. Савроматская эпоха / отв. ред. М.Г. Мошкова. М.: ИА РАН, 1994. 223 с.

12. Статистическая обработка погребальных памятников Азиатской Сарматии. Вып. ІІ. Раннесарматская культура / отв. ред. М.Г. Мошкова. М.: ИА РАН, 1997. $278 \mathrm{c}$.

13. Статистическая обработка погребальных памятников Азиатской Сарматии. Вып. III. Среднесарматская культура / отв. ред. М.Г. Мошкова. М.: Вост. литература, 2002.143 c. 
14. Статистическая обработка погребальных памятников Азиатской Сарматии. Вып. IV. Позднесарматская культура / отв. ред. М.Г. Мошкова. М.: Вост. литература, 2009. $116 \mathrm{c}$.

15. Яблонский Л.Т. Предисловие // Вооружение сарматов: региональная типология и хронология: докл. к VI междунар. конф. «Проблемы сарматской археологии и истории» / отв. ред. Л.Т. Яблонский, А.Д. Таиров. Челябинск: ЮУрГУ, 2007. С. 5

\title{
Сведения об авторах:
}

Хабдулина Марал Калымжановна - кандидат исторических наук, доцент кафедры археологии и этнологии, ЕНУ им. Л.Н. Гумилева (г. Нур-Султан, Казахстан); mk_khabdulina@mail.ru; https://orcid.org/0000-0002-7195-5723

Лукпанова Яна Амангелдиевна - старший научный сотрудник, Западно-Казахстанский центр истории и археологии (г. Уральск, Казахстан); lukpanovayana@gmail.com

\section{МАРИНА ГЛЕБОВНА МОШКАВАНЫН МЕРЕЙТОЙЫНА АРНАЛҒАН ДӨНГЕЛЕК УСТЕЛДІН ЖҰМЫСЫ ТУРАЛЫ}

\author{
М. К. Хабдулина, Я. А. Лукпанова
}

Мақалада 2019 жылғы 12-13 қарашада Мәскеуде РҒА АИ-да өткен тарих ғылымдарының докторы, профессор М.Г. Мошкованың мерейтойына арналған Дөңгелек үстелдің жұмысын талдауға арналған. Сондай-ақ мақалада Марига Глебовна Мошкованың өмірбаянының негізгі кезеңдеріне, оның Еуразия археологиясына, савромат-сармат археологиясының мәселелері бойынша жасаған іргелі зерттеулері мен атқарған жұмыстарына және осы мәдени құбылыстың Еуразия кеңістігіндегі ежелгі қауымдастықтардың тарихындағы рөлін зерттеуге қосқан үлесіне қысқаша шолу жасалынады. М.Г. Мошкованың қатысуымен және редакторлық қызметімен жүзеге асырылған далалық Еуразияның ерте темір ғасырының археологиясы туралы жиынтық еңбектерінің маңызы көрсетілген. Мерейтой иесі аймақтық сарматтанушылардың археологиялық мамандарын дайындауға көмектесіп отырды және үнемі қолдау көрсетті. Мақаланың екінші бөлімінде Дөңгелек үстелге қатысушылардың баяндамаларында айтылған, көтерілген негізгі мәселелерге талдау жасалынады. Олар ертесарматтық археологияны зерттеудің дәстүрлі мәселелеріне: хронология, мерзімдеу, этникалық шығу тегіне қатысты болатын.

Түйін сөздер: археология, М.Г. Мошкова, Еуразия, Оңтүстік Орал, савроматтар, сарматтар, мерзімдеу, хронология, шығу тегі, таңдаулы кешендер

\section{ON THE WORK OF THE ROUND TABLE DEDICATED TO THE ANNIVERSARY OF MARINA G. MOSHKOVA}

\section{K. Khabdulina, Ya. A. Lukpanova}

The article contains an analysis of the work of the Round Table dedicated to the anniversary of the Doctor of Historical Sciences, Professor M. G. Moshkova, which took place in Moscow, in the Institute of Archaeology of the Russian Academy of Sciences on November 12-13, 2019. The article summarizes the main highlights of the biography of Marina G. Moshkova, contribution to the archaeology of Eurasia, to the development and research of fundamental problems of Savromat-sarmatian archaeology and the role of this cultural phenomenon in the history of ancient communities of Eurasian space. The significance of the consolidated works on the archaeology of the Early Iron Age of steppe Eurasia, carried out with the participation and editorial activity of M. G. Moshkova, is indicated. The anniversary celebrant made a huge contribution to the preparation and constant support of 
archaeological personnel of regional schools of Sarmatology. The second part of the article provides an analysis of the main problems voiced in the reports of the participants of the Round Table. They deal with the traditional issues of the study of Early Sarmatian archaeology: chronology, periodization, and ethnicity.

Keywords: archaeology, M. G. Moshkova, Eurasia, South Ural, Savromats, Sarmatians, periodization, chronology, origin, elite complexes

\section{REFERENCES}

1. 60 let kafedre arheologii MGU im. M.V. Lomonosova (60 years old, Department of Archeology M.V. Lomonosov Moscow State University). 1999. Moscow: M.V. Lomonosov Moscow State University Publ. (in Russian).

2. Bokovenko, N. A., Moshkova, M. G., Mogilnikov, V. A. 1992. In Moshkova, M. G. (ed.). Stepi aziatskoy chasti SSSR v skifo-sarmatskoe vremya. Arheologiya SSSR (Steppes of the Asian part of the USSR in Scythian-Sarmatian time. Archeology of the USSR). Moscow: "Nauka" Publ., 151-160 (in Russian).

3. Weinberg, B. V., Gorbunova, G. G., Moshkova, M. G. 1992. In Moshkova, M. G. (ed.). Stepi aziatskoy chasti SSSR v skifo-sarmatskoe vremya. Arheologiya SSSR (Steppes of the Asian part of the USSR in Scythian-Sarmatian time. Archeology of the USSR). Moscow: "Nauka" Publ., 21-30 (in Russian).

4. Melyukova, A. I., Moshkova, M. G. 1989. In Melyukova, A.I. (ed.). Stepi evropeyskoy chasti SSSR v skifo-sarmatskoe vremya. Arheologiya SSSR (Steppes of the European part of the USSR in Scythian-Sarmatian time. Archeology of the USSR). Moscow: "Nauka" Publ., 5-8. (in Russian).

5. Moshkova, M. G. 1956. Proizvodstvo i osnovnoy import u sarmatov Nizhnego Povolzhiya: avtoref. dis. ... kand. ist. nauk (Production and main import on Sarmatians of the Lower Volga: abstract. dis. ... Cand. hist. sciences). Moscow: Institute of the History of Material Culture (in Russian).

6. Moshkova, M. G. 1963. In Svod arheologicheskih istochnikov (Archaeological sources), D1-10. Moscow: "Nauka" Publ. (in Russian).

7. Moshkova, M. G. 1974. Proiskhozhdenie rannesarmatskoy (prohorovskoy) kultury (The origin of the Early Sarmatian (Prokhorov) culture). Moscow: "Nauka" (in Russian).

8. Moshkova, M. G. 1989a. Puti i osobennosti razvitiya "savromato-sarmatskoy» kulturno-istoricheskoy obshchnosti: nauchnyi doklad ... dis. ... dokt. ist. nauk (Ways and features of the development of the "Savromato-Sarmatian" cultural-historical community: scientific report ... Dis. ... doctor Hist. Sciences). Moscow: Institute of Archeology USSR Academy of Sciences (in Russian).

9. Moshkova, M. G. 1989b. In Melyukova, A.I. (ed.). Stepi evropejskoy chasti SSSR $v$ skifo-sarmatskoe vremya. Arheologiya SSSR (Steppes of the European part of the USSR in Scythian-Sarmatian time. Archeology of the USSR). Moscow: "Nauka" Publ., 158-164 (in Russian).

10. Moshkova, M. G. 1989c. In Melyukova, A.I. (ed.). Stepi evropejskoy chasti SSSR $v$ skifo-sarmatskoe vremya. Arheologiya SSSR (Steppes of the European part of the USSR in Scythian-Sarmatian time. Archeology of the USSR). Moscow: "Nauka" Publ., 202-214 (in Russian).

11. Moshkova, M. G. (ed.). 1994. Statisticheskaya obrabotka pogrebalnyh pamyatnikov Aziatskoy Sarmatii. Vyp. I. Savromatskaya epoha (Statistical processing of funeral monuments of Asian Sarmatia. Vol. I. The Savromat era). Moscow: Institute of Archeology RAS (in Russian). 
Хабдулина М.К., Лукианова Я.А. О работе Круглого стола, посвященного юбилею Марины Глебовны Мошковой

12. Moshkova, M. G. (ed.). 1997. Statisticheskaya obrabotka pogrebalnyh pamyatnikov Aziatskoy Sarmatii. Vyp. II. Rannesarmatskaya kultura (Statistical processing of funeral monuments of Asian Sarmatia. Vol. II. Early Sarmatian culture). Moscow: Institute of Archeology RAS (in Russian).

13. Moshkova, M. G. (ed.). 2002. Statisticheskaya obrabotka pogrebalnyh pamyatnikov Aziatskoy Sarmatii. Vyp. III. Srednesarmatskaya kultura (Statistical processing of funeral monuments of Asian Sarmatia. Vol. III. Middle Sarmatian culture). Moscow: "Vostochnaya literature" Publ. (in Russian).

14. Moshkova, M. G. (ed.). 2009. Statisticheskaya obrabotka pogrebalnyh pamyatnikov Aziatskoy Sarmatii. Vyp. IV. Pozdnesarmatskaya kultura (Statistical processing of funeral monuments of Asian Sarmatia. Vol. IV. Late Sarmatian culture). Moscow: "Vostochnaya literature" Publ. (in Russian).

15. Yablonskiy, L. T. 2007. In Yablonskiy, L. T., Tairov, A. D. (eds.). Vooruzhenie sarmatov: regionalnaya tipologiya $i$ hronologiya (Armament of the Sarmatians: regional typology and chronology). Chelyabinsk: South Ural State University Publ., 5 (in Russian).

About the Authors:

Khabdulina Maral K. Candidate of historical sciences, associate professor, L.N. Gumilyov Eurasian National University, Nur-Sultan, Republic of Kazakhstan; mk_khabdulina@mail.ru; https://orcid.org/0000-0002-7195-5723

Lukpanova Yana A. Western Kazakhstan Centre of history and archaeology, Uralsk, Kazakhstan; lukpanovayana@gmail.com 